\title{
Modulation of dendritic cell functions by HTLV-1 with DCs able to direct the presentation of Tax through infected T cells, live virus, and the Tax protein
}

\author{
Sharrón L Manuel', Todd D Schell², Saifur Rahman', Zafar K Khan', Pooja Jain ${ }^{1 *}$ \\ From 15th International Conference on Human Retroviruses: HTLV and Related Viruses \\ Leuven and Gembloux, Belgium. 5-8 June 2011
}

Human T-cell leukemia virus type 1 (HTLV-1) is the etiologic agent of a debilitating neurologic disorder, HTLV-1-associated myelopathy/tropical spastic paraparesis (HAM/TSP). This disease features a robust immune response including the oligoclonal expansion of CD8+ cytotoxic T lymphocytes (CTLs) specific for the viral oncoprotein Tax. The key pathogenic process resulting in the proliferation of CTLs and the presentation of Tax peptide remains uncharacterized. We have investigated the role of APCs, particularly dendritic cells (DCs), in priming of the anti-Tax CTL response under both in vitro and in vivo conditions. We investigated 2 routes (direct versus indirect) of Tax presentation using live virus, infected primary $\mathrm{CD} 4+/ \mathrm{CD} 25+\mathrm{T}$ cells, and the CD4+ T-cell line (C8166, an HTLV-1-mutated line that only expresses Tax). Our results indicated that DCs are capable of priming a pronounced Tax-specific CTL response in cell cultures consisting of naïve PBLs as well as in HLA-A*0201 transgenic mice (line HHD II). DCs were able to successfully direct the presentation of Tax through infected $\mathrm{T}$ cells, live virus, and cell-free Tax. These observations were comparable to those made with a known stimulant of DC maturation - a combination of CD40L and IFN- $\gamma$. Our studies clearly establish a role for this important immune cell component in HTLV-1 immuno/neuropathogenesis and suggest that modulation of DC functions could be an important tool for therapeutic interventions.

\footnotetext{
* Correspondence: pooja.jain@drexelmed.edu

'Department of Microbiology and Immunology, and the Drexel Institute for Biotechnology and Virology Research, Drexel University College of Medicine, Doylestown, PA, 18902, USA

Full list of author information is available at the end of the article
}

\section{Author details}

'Department of Microbiology and Immunology, and the Drexel Institute for Biotechnology and Virology Research, Drexel University College of Medicine, Doylestown, PA, 18902, USA. ²Department of Microbiology and Immunology, Pennsylvania State University College of Medicine, Hershey, PA, USA.

Published: 6 June 2011

doi:10.1186/1742-4690-8-S1-A103

Cite this article as: Manuel et al:: Modulation of dendritic cell functions by HTLV-1 with DCs able to direct the presentation of Tax through infected T cells, live virus, and the Tax protein. Retrovirology 20118 (Suppl 1):A103.
Submit your next manuscript to BioMed Central and take full advantage of:

- Convenient online submission

- Thorough peer review

- No space constraints or color figure charges

- Immediate publication on acceptance

- Inclusion in PubMed, CAS, Scopus and Google Scholar

- Research which is freely available for redistribution

Submit your manuscript at www.biomedcentral.com/submit
() Bïomed Central 